\title{
Appraising the Impact of Gender Differences on Organizational Commitment: Empirical Evidence from a Private SME in Iran
}

\author{
Ashkan Khalili (Corresponding author) \\ Faculty of Management, Multimedia University \\ Jalan Multimedia, 63100 Cyberjaya, Selangor, Malaysia \\ E-mail: ashkankhalili@ymail.com \\ Dr. Arnifa Asmawi \\ Lecturer, Faculty of Management, Multimedia University \\ Jalan Multimedia, 63100 Cyberjaya, Selangor, Malaysia \\ E-mail: arnifa.asmawi@mmu.edu.my
}

Received: August 9, 2011

doi:10.5539/ijbm.v7n5p100
Accepted: January 10, 2012

Published: March 1, 2012

\begin{abstract}
Employee commitment is one of the most important elements that help organizations to achieve their goals. This study investigates the impact of gender differences on organizational commitment. 108 employees of a private small and medium enterprise (SME) company in Iran are randomly selected for this study. The organizational commitment instrument used in this research is adopted from the Allen and Meyer (1990) scale. Based on this scale, three organizational factors (affective commitment, continuance commitment and normative commitment) are evaluated. The findings indicate that men and women have the same level of affective commitment, continuance commitment, and an overall organizational commitment. However results reveal that women have a greater level of normative commitment than men within the SME.
\end{abstract}

Keywords: Organizational commitment, Gender, Private, Small and medium enterprise

\section{Introduction}

Due to spending a substantial time at the workplace, the context of organizational commitment (OC) has attracted remarkable notice. To date, extensive research has been done to investigate the impact of organizational commitment on behavior and attitudes at the workplace (Milliman et al., 2003; Peterson, 2011). Organizational commitment has been investigated as a predictor for several of organizational outcomes as well as specifying organizational effectiveness behavior (Mathieu \& Zajac, 1990; Meyer\& Allen, 1997; Meyer, Stanley, Herscovitch, \& Topolnytsky, 2002; Sinha \& Jain, 2004). Prior studies on outcomes of organizational commitment such as diminishing turnover, lowering absenteeism, increasing organizational citizenship behavior and job performance have been identified in the past thirty years (Mathieu \& Zajac, 1990, Angle \& Perry, 1981; Mowday et al., 1979; Hall, 1977).

Simply put, organizational commitment is defined as the emotional bond or attachment between staff and their firm (Meyer \& Allen, 1997; O'Reilly \& Chatman, 1986). Mowday, Steers and Porter (1979) defined organizational commitment as the relative strength of an individual's identity within particular organization. They describe organizational commitment as "the relative strength of an individual's identification with and involvement in a particular organization. That can be characterized by three factors: (i) a strong belief in and acceptance of the organization's goals and values, (ii) a willingness to exert considerable effort on behalf of the organization, and (iii) a strong desire to maintain membership in the organization."

Indeed small and medium enterprises (SMEs) play a vital role in growth and development of human, social and economic capital. Because of a noteworthy attention to the concept of organizational commitment together with the restricted financial resources and supports for private SMEs in Iran, present study is designed to address whether there is a gender difference between employees of private SMEs or not. Certainly the consequences of 
this paper would help human resource managers of private SMEs to hire individuals (males or females) who are more obligated to the organization.

\section{Literature Review}

Meyer and Allen (1991) argued that organizational commitment is a multidimensional construct. They categorized organizational commitment into three components: affective commitment, continuance commitment and normative commitment (Meyer \& Allen, 1991; Dunham et al., 1994). Affective commitment is identified as "the emotional attachment, identification, and involvement that an employee has with its organization and goals" (Mowday et al, 1979; O’Reily \& Chatman, 1986; Meyer, Allen \& Smith, 1993). Porter et al (1974) further characterized affective commitment by three components (1) "belief in and acceptance of the organization goals and values, (2) a willingness to focus effort on helping the organization to achieve its goals, and (3) a desire to maintain organizational membership". Mowday et al (1979) further stated that affective communication is "when the employee identifies with a particular organization and its goals in order to maintain membership to facilitate the goal."

Table 1 describes the multidimensional terms of organizational commitment. Based on Table 1, scholars believed that organizational commitment includes different terms. Namely, Fields (2002) believed in three dimensions of organizational commitment such as affective, continuance and normative commitment, or McCloskey and McCain (1987) illustrated behavior, attitude and effort as three terms of organizational commitment. Obviously, all scholars perceived organizational commitment as a multidimensional construct which comprises more than one term as depicted in Table 1.

\section{Insert Table 1 here}

Meyer and Allen (1997) claimed that, retaining membership out of own choice by staff reveal that they have commitment to the organization. Continuance commitment is about employee's "nontransferable" investments (such as retirement, relationships with other employees, or things that are special to the organization) in an organization which result from their desire through remaining within an enterprise (Reichers, 1985). In the meantime, factors such as years of employment or benefits that the employee may receive that are exclusive and unique to the company (Reichers, 1985). Furthermore, Meyer and Allen (1997) explained that employees who have nontransferable investment within an organization often do not leave their organization easily, because they share continuance commitment with their employer. That is to say, continuance commitment is educated while individual plays in a way that stakes something which is unrelated to his/her current tasks but valuable and compatible to his/her present behavior cause of awareness from costs of quitting an organization (Becker, 1960).

Normative commitment is a partly new phase of organizational commitment which describes employees' obligation to their workplace or commitment that they have to the organization (Bolon, 1997). In 1982, Weiner defined normative commitment as being a "generalized value of loyalty and duty". In 1991, Meyer and Allen supported Bolon's definition of normative commitment as being "a feeling of obligation". Wiener (1982) claimed that normative commitment is likewise a feeling of having moral commitment to the organization because he believed it is only natural one cause of the way people are raised in society and equal to obligations such as marriage, family, religion, etc.

Meyer, Allen and Smith (1993) identified that the three components of commitment are a psychological statements "that either characterizes the employee's relationship with the organization or has the implications to affect whether the employee will continue with the organization". Totally research shows that employee with a strong affective commitment will remain within a firm because they want to, employee with a strong continuance commitment will remain with an organization cause of they have to and employee with a strong normative commitment will remain because they feel they have to (Meyer et al., 1993).

Fields (2002) defined that, affective commitment is employee's identity with, involvement in, and liking firm, normative commitment is electing feel of commitment to continue employment, while continuance commitment is perceived whenever employees know the cost of associated with leaving the organization.

In other words, organizational commitment associates with many behavioral and organizational outcomes which influence them. For instance, Mathieu and Zajac (1990) identified that there is a positive relationship between organizational commitment and job attendance and negative linear relevance to employee's lateness and turnover. In so doing, one who is obligated to a firm is more likely to remain at work. On the other hand, individual with lower level of commitment may be anticipated to work fewer hours cause of negative relation between organizational commitment and withdrawal behaviors. Batemen and Strasser (1984) asserted that the testimonies for studying organizational commitment are related to "(a) employee behaviors and performance effectiveness, 
(b) attitudinal, affective, and cognitive constructs such as job satisfaction, (c) characteristics of the employee's job and role, such as responsibility and (d) personal characteristics of the employee such as age, job tenure" (p. 95-96).

Employees as the citizens of the organization require performing their obligation that can lead them to crystallize their citizenship behavior within organization. Organizational commitment (OC) is identified in terms of attitude and also a set of intentions. Commitment is an attitude of organization loyalty that exhibited by staff. Attitudinal commitment appears when "the identity of the person is linked to the organization" (Sheldon, 1971) or "when the goals of the organization and those of the individual become increasingly integrated or congruent" (Hall, Schneider \& Nygren, 1970).

Obligation ramifies from individual's belief when they thought organization goals and objectives are compatible with their own. Mowday, Porter and steer (1982) claimed that, commitment is the "relative strength of an individual's identification with and involvement in the organization" in term of goals and values. Ostroff (1992) reported that organization with committed staff has better performance, lower level of absenteeism and low turnover rate.

Concept of organizational commitment has been examined to elucidate its meaning in terms of organization, career, norms, identification, morals, jobs, job involvement, security and more (Meyer \&Allen 1991, Cohen 1993). Allen and Meyer (1990) and Mathieu and Zajac (1990) asserted factors such as age and tenure tend to co-vary with individual's position in the company and are known positively relate with obligation. More years experiences in the firm raises one's psychological attachment and internalization of norms.

Organizational commitment has been conceptualized and measured in various ways same as many other constructs in organizational psychology. Prevalently to all conceptualization of obligation, committed employees are defined who are strongly obligated and least likely to leave the organization. Pfeffer (1998) observed that individuals who are highly motivated to participate their time and energy to follow organizational goals are classified as committed employees and organization's primary asset. Meyer and Allen (1997) identified a committed employee who is "stays with an organization, attends work regularly, puts in a full day and more, protects corporate assets, and believes in the organizational goals".

Obligated individual is more likely to exhibit organization-serving behavior (O'Reilly \& Chatman, 1986). This demeanor directly or indirectly benefits the work unit, the company and some other employees. For instance, if employee works more hours in the organization they may serve the work unit (group), firm or co-workers by that issue. Project managers that stay late at the workplace can be available to co-workers to answer any technical questions or assist them with difficulties even they are not producing measurable work results. And also managers' presence may motivate other staff. In so doing, managers are helping the work group, firm and subordinates.

Particularly, employees must be given several opportunities to feel obligation to the organization. That is to say, building a good relationship with immediate work group can increase level of commitment in the workplace (Meyer \& Allen, 1997). On the other hand, Lio (1995) claimed that perception of job security plays a vital role in constructing staff's commitment in an organization. Manager's style is another issue that impacts employees' obligation, because employees who favored their manager's style also making favored commitment to the organization and the level of that (Koopman, 1991). Nierhoff et al (1990) identified that the "overall management culture and style driven by the top management actions are strongly related to the degree of employee commitment". Manager's conscious about their responsibilities as well as giving reward and support for the tasks that staff do are other issues that rise employee's involvement which makes them more innovative and build their trust to both managers and organization (Eisenberger et al., 1990).

In growing economies such as Iran the role of small and medium enterprises is very significant, because SMEs are the main mechanisms in private sector to discover and create new markets. Taylor (2006) disclosed that 25 percent of small businesses are faced with a shortage of qualified employees that not only inhibits the growth and development but also it is a threat to their survival. Hence due to the foregoing reasons, it is necessary to conduct the current study to find out whether there is a significant difference between employees' (males and females) obligation or not. Indeed, the consequences of present research would help SMEs to prevent from wasting their financial resources through retaining qualified employees to boost their level of commitment and/or by hiring more obligated individuals. 


\section{Methodology}

Current research is conducted on 108 employees (54 men and 54 women) of LAR Consulting Engineers Company which is a private small and medium enterprise (SME) in Iran. LAR Consulting Engineers (LCE) Company established in 1983 as subsidiary of Ministry of Energy - Tehran Regional water Authority and later in 1986 it became registered private company. In order to develop a self-sufficient water industry in the country, LAR is tasked to manage the construction of LAR Dam. LAR is now gradually replacing foreign consultants with local expertise. In order to boost organizational productivity, it is imperative that the company makes an assessment on the existing level of its employee commitment. The organizational commitment instrument used in this research is adopted from the Allen and Meyer (1990) scale. Based on this scale (Table 2), three organizational factors (affective commitment, continuance commitment and normative commitment) are evaluated. The assessment provides an overall organizational commitment score as well as a score in each of the three organizational commitment factors. Statements from 1 to 8 illustrate respondents' affective commitment, statements from 9 to 16 estimate respondents' continuance commitment, while statements 17 to 24 appraise respondents' normative commitment. The respondents are requested to indicate the extent that each statement characterized them using the five Likert scale format from 1 (Strongly disagree) to 5 (Strongly agree). In this scale, nine negatively items (questions $4,5,6,8,9,12,18,19$, and 24) are reverse coded.

Insert Table 2 here

\subsection{Hypothesis Development}

Scholars asserted that personal characteristics such as gender, age, and organizational tenure would predict organizational commitment (Meyer \& Allen, 1997). Furthermore, gender has been considered in organizational commitment literature from two aspects: the job model and the gender model (Aven, Parker, \& McEvoy, 1993). The job model approach indicated that there are no differences in the work attitudes of males and females; and work attitudes of men and women extended in similar ways (Loscocco, 1990). On the contrary, advocates of gender model in the study of organizational commitment and females disclosed that "women accept family roles as a chief source of their identity and fulfillment, leading to a different orientation to work for men, for whom work is paramount" (Loscocco, 1990, p. 155).

Prior empirically studies reported the differences in organizational commitment between males and females. To be more elaborate, scholars through meta-analytic study found that there are vital differences in employee's obligation between men and women (Mathieu \& Zajac, 1990). Previous researches suggested that men are more committed to their firms (Kaldenberg et aI., 1995; Dodd-McCue \& Wright, 1996). Based on a study that examined the relationship of organizational commitment and gender differences between 1,040 Canadian Charter Accountants, women illustrated lower level of organizational commitment than men (Aranya, Kushnir, \& Valency, 1986). Also some researchers claimed that females are more obligated to their organizations (Matthieu \& Zajec, 1990; Marsden et al., 1993; Wahn, 1998).

Marsden et al (1993) asserted that men and women present similar levels of organizational commitment if they work under equivalent work conditions. According to the meta-analysis of studies that investigated the relevance of organizational commitment and gender, there are no significant difference among men and women whenever organizations treat all staff fairly (Aven, Parker \& McEvoy, 1993). Furthermore, some other scholars found that there is no relationship between organizational commitment and gender differences (Aven, Parker \& McEvoy, 1993; Savicki, Cooly \& Gjesvold, 2003; AI-Ajmi, 2006).

Moreover, Ngo and Tsang (1998) claimed that executives' organizational commitment is not affected by gender differences. Their study (772 respondents) conducted to examine whether gender differences impacts on business executives in Hong Kong or not.

Therefore, present study examines the impact of gender differences on organizational commitment between employees of small and medium enterprise in private sector. So, three sub-hypotheses and one main research hypothesis are formulated as below:

Sub-hypotheses:

H1: Males and females have the same level of affective commitment.

$\mathrm{H} 2$ : Male and females have the same level of continuance commitment.

H3: Male and females have the same level of normative commitment.

Main hypothesis:

H4: Males and females have the same level of organizational commitment. 


\subsection{Method of Analysis}

The Cronbach Alpha method is used to determine the reliability of each variable. Then The Independent-Samples $\mathrm{T}$ Test conducts to compare means for two groups of employees (men=54, women=54). Mean and Std. Deviation of each organizational commitment components as well as organizational commitment as a whole construct are measured to identify whether there is a gender difference between employees' obligation or not, and also to find out which components of organizational commitment are significantly different between males and females.

\section{Data Analysis}

The Cronbach Alpha method is used to determine the reliability of each component (affective commitment, continuance commitment and normative commitment), and an overall organizational commitment which make up the research instrument. The Cronbach Alpha method determines the inter-item correlation among the items measuring the construct. As illustrates in Table 3, the Cronbach Alpha value ranged from 0.72 to 0.78 . As the Cronbach's Alpha in this study is within the acceptable range, the constructs are therefore deemed to have adequate reliability and ready for actual survey.

\section{Insert Table 3 here}

Table 4 (Mean and Standard Deviation for Organizational Commitment) demonstrates differences between mean scores of males and females in their commitment to the organization. For affective commitment men (mean=3.77; $\mathrm{S} . \mathrm{D}=0.812$ ) reveals greater tendency in compare with women (mean=3.54; $\mathrm{S} . \mathrm{D}=0.861$ ). The second component which is continuance commitment receives more tendency by men (mean=3.74; $\mathrm{S} . \mathrm{D}=0.791$ ). But, result shows that women have higher level of normative commitment (mean=3.57; S.D $=0.573$ ) in compare with men (mean=3.26; S.D $=0.557$ ).

\section{Insert Table 4 here}

Regarding organizational commitment as a whole construct, current research finding illustrates that men (mean=3.79; $\mathrm{S} . \mathrm{D}=0.527$ ) scored more than women (mean=3.63; $\mathrm{S} . \mathrm{D}=0.523$ ).

Independent sample $T$ test reveals that affective commitment ( $\mathrm{p}$-value $=0.457>0.05)$, continuance commitment $(p$-value $=0.067>0.05)$, normative commitment $(p$-value $=0.912>0.05)$, and organizational commitment (p-value $=0.129>0.05)$ are all homogeneous with different types of gender, because the variances are not different at $\alpha=0.05$ as presented in Table 5 .

\section{Insert Table 5 here}

According to Table 6 (Test for Equality on Means), affective commitment ( $\mathrm{p}$-value $=0.147>0.05$ ), continuance commitment ( $p$-value $=0.633>0.05)$, and organizational commitment $(p$-value $=0.105>0.05)$ are all beyond $\alpha=0.05$ which means that there are no significant differences in three components of organizational commitment together with organizational commitment as a whole construct between men and women. Since the par value for affective commitment, continuance commitment and an overall organizational commitment are higher than $\alpha=0.05$, thus there is no difference based on these three variables between males and females. On the contrary, finding shows that there is a significant difference in normative commitment ( $p$-value $=0.006<0.05$ ) among men and women.

\section{Insert Table 6 here}

Since the p-value of normative commitment is 0.006 (which is less than $\alpha=0.05$ ), there is some evidence based on ranking (Table 7) that there is a significant difference in normative commitment between males and females.

\section{Insert Table 7 here}

The mean rank (Table 7) for men is 47.76 while for women is 61.24 . Therefore, females have higher level of normative commitment to the organization than males.

Furthermore, Table 8 (Summary of the Findings) is provided to present the result of all tests to understand whether the research hypotheses are accepted or rejected.

\section{Insert Table 8 here}

Based on findings, affective commitment (H1), continuance commitment (H2), and organizational commitment (H4), are not significantly different between men and women. In contrast, normative commitment (H3) seems to be different among males and females. 


\section{Discussions}

Since organizational commitment is allied with whether and for what reason employees stay with a firm (Meyer \& Allen, 1997), the purpose of present study is to examine gender differences in three components of organizational commitment (OC) as well as $\mathrm{OC}$ as a whole construct. Totally previous research identified that staff with a strong affective commitment will remain within a firm because they want to, employee with a strong continuance commitment will remain with an organization cause of they have to and staff with a strong normative commitment will remain because they feel they have to (Meyer et al., 1993).

In current research men participants illustrates higher level of affective commitment (mean=3.77; S.D $=0.812$ ), continuance commitment (mean $=3.74 ; \mathrm{S} . \mathrm{D}=0.791$ ), and an overall organizational commitment (mean=3.79; $\mathrm{S} . \mathrm{D}=0.527$ ) in compare with women. On the contrary, females (mean=3.57; $\mathrm{S} . \mathrm{D}=0.573$ ) demonstrates that they have more normative commitment to the organization than males (mean=3.26; S.D=0.557). The results of present manuscript on perceiving organizational commitment (OC) as a whole construct are in line with the outcomes of studies reported by Kaldenberg et al (1995), Dodd-McCue and Wright (1996). They all found that males have higher level of organizational commitment than females.

In the meantime, this study shows that there are no significant differences in two components of organizational commitment: affective commitment $(p$-value $=0.147>0.05)$ and continuance commitment ( $p$-value $=0.633>$ 0.05 ), together with an overall organizational commitment ( $p$-value $=0.105>0.05$ ) between different types of gender. But based on findings, employees' gender differences have significant impact on their perception of normative commitment ( $\mathrm{p}$-value $=0.006<0.05$ ).

Clearly, highly obligated employees will attach with goals of the enterprise, have stronger tendency to belong to the organization, and are willing to exhibit greater behavior and attitudes. In this research males presented higher level of affective commitment and continuance commitment. This shows that males are more willingness to be with the firm goals and values because they think the organization has a great deal of meaning to them, and also "they have to" be because of the organization benefits as well as their necessity it would be costly to leave it. On the other hand, women presented higher level of normative commitment which reveals that they are more loyal to the organization than men because "they feel they have to" be with the organization (Meyer et al., 1993). Furthermore, by reviewing previous reports, current research found that other personal characteristics have different influences on organizational commitment. For instance, age (Mathieu \& Zajac, 1990) and marital status (John \& Taylor, 1999) are positively related to organizational commitment. Meanwhile, the negative impact of employees' educational level (Glisson \& Durick, 1988) on their organizational obligation is reported.

\section{Conclusions and Recommendations for Future Research}

The findings of this research provide valuable recommendations and implications for continued exploration of employees' obligation in private small and medium enterprises. There is a need to evaluate the gender differences through small and medium enterprises in various types of industries, including technology-based, human service, or non-profit organizations. Future studies can be done by larger sample size. For instance, it is suggested that this research be replicated with collecting data from numerous small and medium enterprises. It would be interesting to explore, if a larger sample size would conclude in significant differences from current research.

Moreover scholars asserted that personal characteristics such as gender, age, and organizational tenure would predict organizational commitment (Meyer \& Allen, 1997). While this study is investigated gender differences, future researches can examine other personal characteristics such as age and organizational tenure within employees of private small and medium enterprises in private sector.

\section{References}

AI-Ajmi, R. (2006). The effect of gender on job satisfaction and organizational commitment in Kuwait. International Journal of Management, 23(4), 838-844.

Allen, N. J., \& Meyer, J. P. (1990). The measurement and antecedents of affective, continuance, and normative commitment to the organization. Journal of Occupational Psychology, 63, 1-18.

Angle, H. L., \& Perry, J. L. (1981). An empirical assessment of organization commitment and organizational effectiveness. Administrative Science Quarterly, 26, 1-13.

Aranya, N., Kushnir, T., \& Valency, A. (1986). Organizational commitment in a male-dominated profession. Human Relations, 39(5), 433-448. http://dx.doi.org/10.1177/001872678603900504 
Aven, F., Parker, B., \& McEvoy, G. (1993). Gender and attitudinal commitment to organizations: a metaanalysis. Journal of Business Research, 26, 49-61.

Bateman, T., \& Strasser, S. (1984). A longitudinal analysis of the antecedents of organizational commitment. Academy of Management Journal, 27(1), 95-112. http://dx.doi.org/10.2307/255959

Becker, H.S. (1960). Notes on the content of commitment. American Journal of Sociology, 66, 32-42.

Bolon, D. S. (1997). Organizational Citizenship Behavior Among Hospital Employees: A Multidimensional Analysis Involving job Satisfaction and Organizational Commitment. Hospital \& Health Services Administration, 42(2), 221-241.

Cheryl M, Wagner. (2007). Organizational commitment as a predictor variable in nursing turnover research: literature review. Journal of Advanced Nursing, 60(3), 235-247.

Cohen, A. (1993). Work commitment in relation to withdrawal intentions and union effectiveness. Journal of Business Research, 26(1), 75-90. http://dx.doi.org/10.1016/0148-2963(93)90044-P

Corley, M.C., \& Mauksch, H.O. (1993). The nurse's multiple commitments. Journal of Professional Nursing, 9(2), 116-122. http://dx.doi.org/10.1016/8755-7223(93)90028-B

Dodd-McCue, D., \& Wright, G. (1996). Men, women, and attitudinal commitment: the effects of workplace

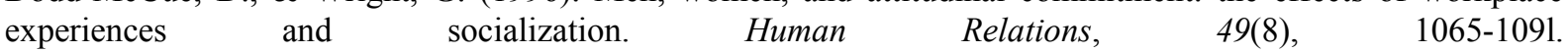
http://dx.doi.org/10.1177/001872679604900803

Dunham, R.B., Grube, J.A., \& Castenada, M.B. (1994). Organizational commitment: The utility of an integrative definition. Journal of Applied Psychology, 79(3), 370-380. http://dx.doi.org/10.1037//0021-9010.79.3.370

Eisenberger, R., Fasolo, P., \& Davis-LaMastro, V. (1990). Perceived Organizational Support and Employee Diligence, Commitment, and Innovation. Journal of Applied Psychology, 75(1), 51-59. http://dx.doi.org/10.1037//0021-9010.75.1.51

Etzioni, A. (1961). A Comparative Analysis of Complex Organizations. Free Press, Glencoe, NY.

Fields, D. (2002). Taking the Measure of Work: A Guide to Validated Scales for Organizational Research and Diagnosis. Sage Publications, Thousand Oaks, CA.

Finegan, J., Shamian, J., \& Laschinger, H.K.S. (2001). The impact of workplace empowerment, organizational trust on staff nurses' work satisfaction and organizational commitment. Health Care Management Review, 26(3), $7-23$.

Friss, L. (1983). Organization commitment and job involvement of directors of nursing services. Nursing Administration Quarterly, 7(2), 1-10.

Glisson, C., \& Durick, M. (1988). Predictors of job satisfaction and organizational commitment in human service organizations. Administrative Science Quarterly, 33(1), 61-81. http://dx.doi.org/10.2307/2392855

Hall, D. (1977). Organizational identification as a function of career pattern and organizational type. Administrative Science Quarterly, 17(3), 340-350. http://dx.doi.org/10.2307/2392147

Hall, D. T., Schneider, B., \& Nygren, H. T. (1970). Personal factors in organizational identification. Administrative Science Quarterly, 15(2), 176-190. http://dx.doi.org/10.2307/2391488

John, M. C., \& Taylor, W. T. (1999). Leadership style, school climate and the institutional commitment of teachers. International Forum (InFo), 2(1), 25-57.

Kaldenberg, D., Becker, B., \& Zvonkovic, A. (1995). Work and commitment among young professionals: a study of male and female dentists. Human Relations, 48(11), 1355-1377. http://dx.doi.org/10.1177/001872679504801106

Koh, S. C. L., \& Maguire, S. (2004). Identifying the adoption of e-business and knowledge management within SMEs. Journal of Small Business and Enterprise Development, 11(3), 338-348. http://dx.doi.org/10.1108/14626000410551591

Koopman, P.L. (1991). Between control and commitment: Management and change as the art of balancing. Leadership and OD Journal, 12(5), 3-7. http://dx.doi.org/10.1108/01437739110004947

Laschinger, H. K. S., Finegan, J., Shamian, J., \& Casier, S. (2000). Organizational trust and empowerment in restructured healthcare settings: effects on staff nurse commitment. Journal of Nursing Administration, 30(9), 413-425. 
Lio, Kutsai. (1995). Professional orientation and organizational commitment among public employees: an empirical study of detention workers. Journal of Public Administration Research and Theory, 5, 231-246.

Loscocco, K. A. (1990). Reactions to blue-collar work: A comparison of women and men. Work and Occupations, 17(2), 152-177. http://dx.doi.org/10.1177/0730888490017002002

Manion, J. (2004). Strengthening organizational commitment: understanding the concept as a basis for creating effective workforce retention strategies. Health Care Manager, 23(2), 167-176.

Marsden, P., Kalleberg, A., \& Cook, C. (1993). Gender differences in organizational commitment: influences of work positions and family roles. Work and Occupations, 20(3), 368-390. http://dx.doi.org/10.1177/0730888493020003005

Mathieu, J. E., \& Zajac, D. M. (1990). A review and meta-analysis of the antecedents, correlates and consequences of organizational commitment. Psychological Bulletin, 108(2), 171-194. http://dx.doi.org/10.1037//0033-2909.108.2.171

McCloskey, J. C., \& McCain, B. E. (1987). Satisfaction, commitment and professionalism of newly employed nurses. Image: Journal of Nursing Scholarship, 19(1), 20-24. http://dx.doi.org/10.1111/j.1547-5069.1987.tb00581.x

Meyer, J. P., Allen, N. J., \& Smith, C. A. (1993). Commitment to Organizations and Occupations: Extension and Test of a Three-Component Conceptualization. Journal of Applied Psychology, 78(4), 538-552. http://dx.doi.org/10.1037//0021-9010.78.4.538

Meyer, J. R., \& Allen, N. J. (1991). A three-component conceptualization of organizational commitment. Human Resource Management Review, 1(1), 61-89. http://dx.doi.org/10.1016/1053-4822(91)90011-Z

Meyer, J.P., \& Allen, N.J. (1997). Commitment in the Workplace: Theory, Research, and Application. Thousand Oaks, CA: Sage Publications.

Meyer, P. J., Stanley, D. J., Herscovitch, L., \& Topolnytsky, L. (2002). Affective, continuance, and normative commitment to the organization: A meta-analysis of antecedents, correlates, and consequences. Journal of Vocational Behavior, 61(1), 20-52. http://dx.doi.org/10.1006/jvbe.2001.1842

Milliman, J., Andrew, J., Czaplewski \& Ferguson, J. (2003). Workplace spirituality and employee work attitudes: An exploratory empirical assessment. Journal of Organizational Change Management, 16(4), 426-447. http://dx.doi.org/10.1108/09534810310484172

Morrow, P. (1983). Concept redundancy in organizational research: The case of work commitment. Academy of Management Review, 8(3), 486-500. http://dx.doi.org/10.2307/257837

Mowday, R. T., Porter, L. M., \& Steers, R. M. (1982). Employee-organization linkages: The psychology of commitment, absenteeism and turnover. New York, NY: Academic Press.

Mowday, R., Porter, L., \& Steers, R. (1979). The measurement of organizational commitment. Journal of Vocational Behavior, 14(2), 224-247. http://dx.doi.org/10.1016/0001-8791(79)90072-1

Ngo, H., \& Tsang, A. (1998). Employment practices and organizational commitment: differential effects for men and women? International Journal of Organizational Analysis, 6(3), 251-266. http://dx.doi.org/10.1108/eb028887

Niehoff, B. P., Enz, C. A., \& Grover, R. A. (1990). The impact of top-management actions on employee attitudes and perceptions. Group \& Organization Studies, 15(3), 337-352. http://dx.doi.org/10.1177/105960119001500307

O'Reilly, C. A., \& Chatman, J. (1986). Organizational commitment and psychological attachment: The effects of compliance, identification and internalization on pro social behavior. Journal of Applied Psychology, 71(3), 492-499. http://dx.doi.org/10.1037//0021-9010.71.3.492

Ostroff, C. (1992). The Relationship between Satisfaction, Attitudes, and Performance: An Organizational Level Analysis. Journal of Applied Psychology, 77(6), 963-974. http://dx.doi.org/10.1037//0021-9010.77.6.963

Penley, L. E., \& Gould, S. (1988). Etzioni's model of organizational involvement: a perspective for understanding commitment to organizations. Journal of Organizational Behavior, 9(1), 43-59. http://dx.doi.org/10.1002/job.4030090105

Peterson, D. k. (2011). Compromiso Es Una Blanco Movil: A Study of Organizational Commitment in Mexico. Global Journal of Management and Business Research, 11(3), 99-110. 
Pfeffer, J. (1998). The Human Equation: Building profits by putting people first. Boston, Harvard Business School Press.

Porter, L. W., Steers, R. M., Mowday, R. T., \& Boulian, P. V. (1974). Organizational commitment, job satisfaction, and turnover among psychiatric technicians. Journal of Applied Psychology, 59(5), 603-609. http://dx.doi.org/10.1037/h0037335

Reichers, A. (1985). A review and reconceptialitzion of organizational commitment. The Academy of Management Review, 10(3), 465-476.

Savicki, V., Cooley, E., \& Gjesvold, J. (2003). A Harassment as a predictor of job burnout in correctional officers. Criminal Justice and Behavior, 30(5), 602-619. http://dx.doi.org/10.1177/0093854803254494

Sheldon, M. E. (1971). Investments and involvements as mechanisms producing commitment to the organization. Administrative Science Quarterly, 16(2), 143-150. http://dx.doi.org/10.2307/2391824

Sinha, A. K., \& Jain, A. K. (2004). Emotional intelligence: Imperative for the organizationally relevant outcomes. Psychological Studies, 49, 81-96.

Stinglhamber, F., Bentein, K., \& Vandenberghe, C. (2002). Extension of the three-component model of commitment to five foci. European Journal of Psychological Assessment, 18(2), 123-138. http://dx.doi.org/10.1027//1015-5759.18.2.123

Taylor, S. (2006). Acquaintance, meritocracy and critical realism: Researching recruitment and selection processes in smaller and growth organizations. Human Resource Management Review, 16(4), 478-489. http://dx.doi.org/10.1016/j.hrmr.2006.08.005

Wahn, J. (1998). Sex differences in the continuance component of organizational commitment. Group and Organization Management, 23(3), 256-66. http://dx.doi.org/10.1177/1059601198233004

Weiner, Y. (1982). Commitment in Organization: A Normative View. Academy of Management Review, 7 , 418-428.

Zangaro, G. A. (2001). Organizational commitment: a concept analysis. Nursing Forum, 36(2), 14-22. http://dx.doi.org/10.1111/j.1744-6198.2001.tb01179.x

Table 1. Organizational Commitment Multidimensional Terms

\begin{tabular}{|l|l|}
\hline \multicolumn{1}{|c|}{ Source } & \multicolumn{1}{c|}{ Terms used } \\
\hline Corley and Mauksch (1993) & Professional, work, organizational and patient commitment \\
\hline Etzioni (1961) & Morally, calculatively and alienatively committed \\
\hline Fields (2002) & Affective, normative and continuance commitment \\
\hline Finegan et al. (2001) & Affective, normative and continuance commitment \\
\hline Friss (1983) & Attitude or belief, desire and effort \\
\hline Laschinger et al. (2000) & Affective, normative and continuance commitment \\
\hline Manion (2004) & Affective, normative and continuance commitment \\
\hline McCloskey and McCain (1987) & Behavior, attitude and effort \\
\hline Meyer and Allen (1991) & Affective, normative and continuance commitment \\
\hline Mowday et al. (1982) & Behavior, attitude and effort \\
\hline Mowday et al. (1979) & Behavior, attitude and effort \\
\hline Penley and Gould (1988) & Morally, calculatively and alienatively committed \\
\hline Potter et al. (1974) & Belief, effort and desire \\
\hline $\begin{array}{l}\text { Porter and Smith (un-publish data, The } \\
\text { University of California at Irvine, Irvine, } \\
\text { CA, USA) }\end{array}$ & Behavior, attitude and effort \\
\hline Reichers (1985) & Identification of goals and commitment \\
\hline Stinglhamber et al. (2002) & $\begin{array}{l}\text { Affective, normative and continuance commitment; } \\
\text { organizational, occupational, work group and } \\
\text { supervisor/customer }\end{array}$ \\
\hline Zangaro (2001) & Morally, calculatively and alienatively committed \\
\hline
\end{tabular}

Adopted from: Cheryl M. Wagner (2007) "Organizational commitment as a predictor variable in nursing turnover research: literature review" 
Table 2. Measurement Items for Organizational Commitment

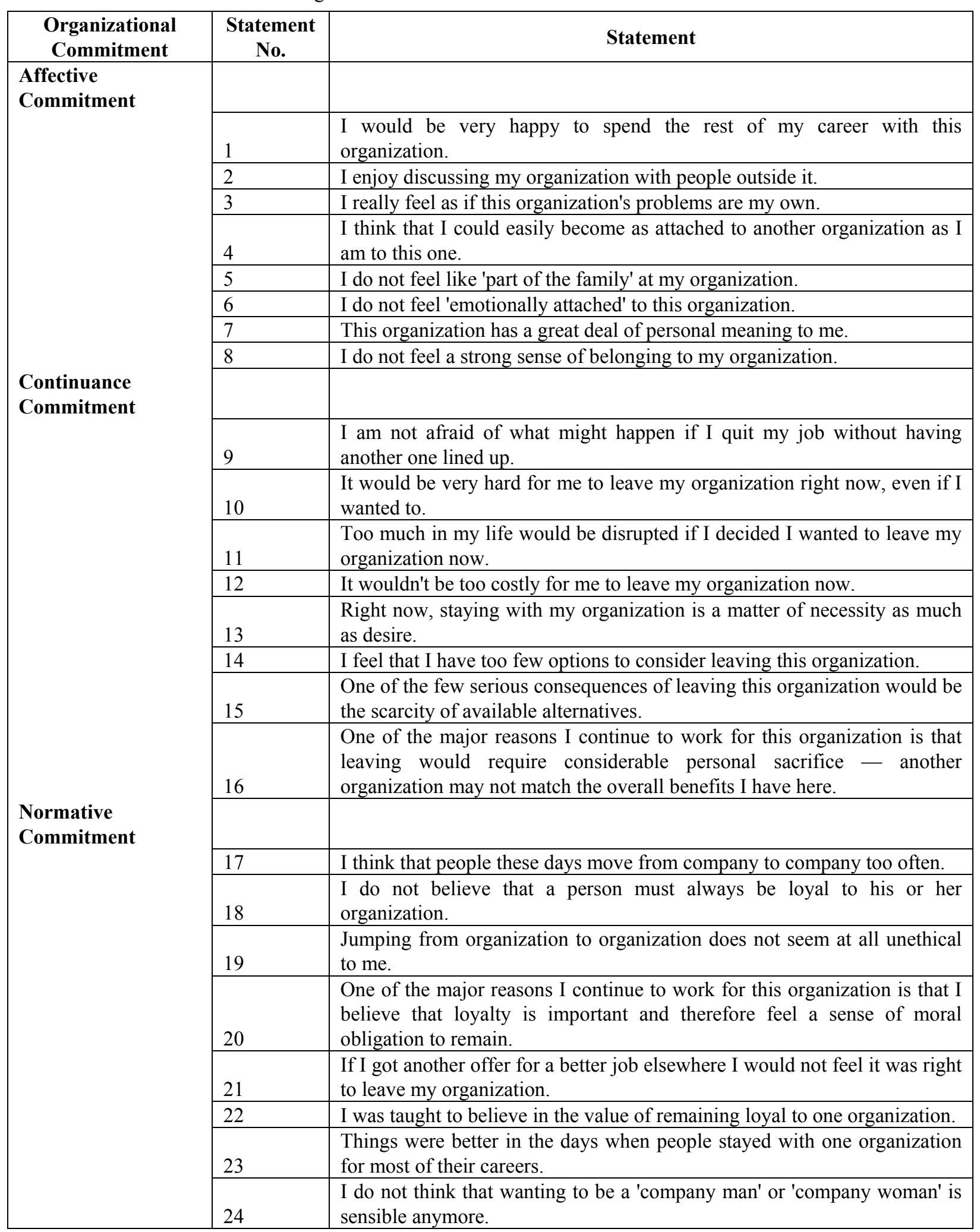

Adopted from: Allen \& Meyer (1990): "The measurement and antecedents of affective, continuance, and normative commitment to the organization" 
Table 3. Reliability Statistics of the Research Constructs in the Questionnaires

\begin{tabular}{|c|c|}
\hline Variables & Cronbach Alpha \\
\hline Affective Commitment & 0.78 \\
\hline Continuance Commitment & 0.75 \\
\hline Normative Commitment & 0.72 \\
\hline Organizational commitment & 0.77 \\
\hline
\end{tabular}

Table 4. Mean and Standard Deviation for Organizational Commitment

\begin{tabular}{|c|c|c|c|}
\hline Variables & Sex & Mean & Std. Deviation \\
\hline Affective & Male & 3.77 & .812 \\
Commitment & Female & 3.54 & .861 \\
\hline Continuance & Male & 3.74 & .791 \\
Commitment & Female & 3.67 & .647 \\
\hline Normative & Male & 3.26 & .557 \\
Commitment & Female & 3.57 & .573 \\
\hline Organizational & Male & 3.79 & .527 \\
Commitment & Female & 3.63 & .523 \\
\hline
\end{tabular}

Table 5. Levene's Test (Test for Equality Variance)

\begin{tabular}{|c|c|}
\hline Variables & Sig.* \\
\hline Affective Commitment & .457 \\
\hline Continuance Commitment & .067 \\
\hline Normative Commitment & .912 \\
\hline Organizational Commitment & .129 \\
\hline
\end{tabular}

Note: * significant at $\mathrm{p}=0.05$ level

Table 6. Test for Equality on Means

\begin{tabular}{|c|c|}
\hline Variables & Sig. (2-tailed) * \\
\hline Affective Commitment & .147 \\
\hline Continuance Commitment & .633 \\
\hline Normative Commitment & $.006^{*}$ \\
\hline Organizational Commitment & .105 \\
\hline
\end{tabular}

Note: * Significant at $\mathrm{p}=0.05$ level

Table 7. Ranks

\begin{tabular}{|c|c|c|c|c|}
\hline Variable & Sex & N & Mean Rank & Sum of Ranks \\
\hline Normative & Male & 54 & 47.76 & 2579.00 \\
Commitment & Female & 54 & 61.24 & 3307.00 \\
& Total & 108 & & \\
\hline
\end{tabular}

Table 8. Summary of the Findings

\begin{tabular}{|c|c|}
\hline Hypothesis & Result \\
\hline H1 & Accept \\
\hline H2 & Accept \\
\hline H3 & Reject \\
\hline H4 & Accept \\
\hline
\end{tabular}

